\title{
Mouse ES cells over-expressing the transcription factor NeuroD1 show increased differentiation towards endocrine lineages and insulin-expressing cells
}

\author{
MÉLANIE MARCHAND $1,2,3,4,5$, INSA S. SCHROEDER ${ }^{6}$, SUZY MARKOSSIAN $1,2,3,4$, ANOUCHKA SKOUDY ${ }^{7}$, \\ DIDIER NĖGRE ${ }^{3,4,10,11}$, FRANÇOIS-LOÏC COSSET $3,4,10,11$, PACO REAL 7,8,9, CHRISTIAN KAISER ${ }^{6}$, \\ ANNA M. WOBUS ${ }^{6}$ and PIERRE SAVATIER ${ }^{1,2,3, *}$
}

\begin{abstract}
${ }^{1}$ Inserm, U846 and ${ }^{2}$ Stem Cell and Brain Research Institute, Bron, France, ${ }^{3}$ Université de Lyon and ${ }^{4}$ Université Lyon I, Lyon, France, ${ }^{5}$ Institute for Stem Cell Biology and Regenerative Medicine, Stanford University, Stanford, CA, USA, ${ }^{6}$ In vitro Differentiation Group, Leibniz Institute of Plant Genetics and Crop Plant Research (IPK) Gatersleben, Germany, ${ }^{7}$ Cell and Molecular Biology Unit, Institut Municipal d'Investigació Mèdica (IMIM), Barcelona, Spain, ${ }^{8}$ Departament de Ciències Experimentals I de la Salut, Universitat Pompeu Fabra, Barcelona, Spain, ${ }^{9}$ Centro Nacional de Investigaciones Oncologicas (CNIO), Madrid, Spain, 10Inserm, U758, Human Virology Department and ${ }^{11}$ Ecole Normale Supérieure de Lyon, Lyon, France
\end{abstract}

\begin{abstract}
Embryonic stem (ES) cells which constitutively express the Pdx-1, Ngn-3, NeuroD1, Nkx2.2, and Nkx6.1 transcription factors were engineered by means of lentiviral vectors, following a multi-step infection procedure to successively generate ES cell lines expressing one, two, and three factors, respectively. Each ES cell line was allowed to differentiate into nestin+//sI-1+ endocrine precursors, then into more mature pancreatic cells, and subsequently analysed for expression of Glc, Ins, and Sst, markers of $\alpha, \beta$ and $\delta$ cells, respectively. Each ES cell line generated displayed a unique pattern of gene expression. The ES cell line expressing NeuroD1 displayed vastly elevated levels of GIc, Ins-1, Ins-2 and Sst, and showed an increase in Pdx-1, Pax-4, Nkx6.1, IsI-1, Glut-2 and $G K$ transcript levels. Furthermore, immunofluorescence analysis revealed that

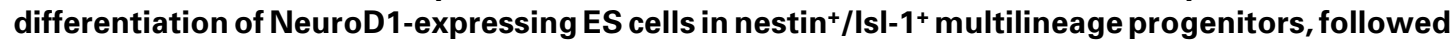
by the formation of $\mathrm{C}$-peptide $/$ insulin+ clusters, was accelerated. Together, these results indicate that stable expression of NeuroD1 in ES cells facilitates differentiation into endocrine and insulinproducing cells.
\end{abstract}

KEY WORDS: embryonic stem, endocrine differentiation, insulin, NeuroD1, lentiviral vector

\section{Introduction}

Embryonic stem (ES) cells are derived from the pluripotent cells of the blastocyst stage embryo. They are able to self-renew indefinitely in vitro while retaining pluripotency and to differentiate into diverse cell types of ectodermal, mesodermal and endodermal lineages (Smith, 2001; Wobus and Boheler, 2005). The differentiation of ES cells into insulin-producing $\beta$-like cells constitutes a field of intensive investigations as it represents a possible alternative both to the use of immortalized endocrine cell lines for drug screening and functional genomics and to the limited availability of human islets needed for transplantation in type I diabetes therapy (Blyszczuk et al., 2004; Bonner-Weir and Weir, 2005; Nir and Dor, 2005).

The pancreas is a heterogeneous organ composed by exocrine, ductal and endocrine cells. The exocrine compartment is responsible for the production of digestive enzymes, which are transported through pancreatic ducts formed by ductal cells. The endocrine compartment, organized in islets of Langerhans, is

\footnotetext{
Abbreviations used in this paper: BrdU, 5-bromo-2'-deoxyuridine; BSA, bovine serum albumin; EB, embryoid body; ES, embryonic stem; CK, cytokeratin; GMEM, Glasgow's modified Eagle's medium; FCS, fetal calf serum; GFP, green fluorescent protein ; GK, glucokinase; LIF, leukemia inhibitory factor; M-MLV, Moloney- murine leukemia virus; RPM, rotation per minute; RT-PCR, reverse transcriptase - polymerase chain reaction.
}

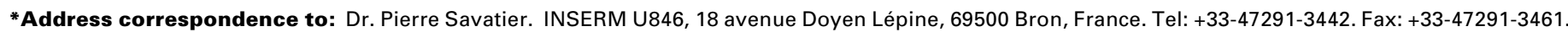
e-mail: pierre.savatier@inserm.fr - Web: http://wwwsbri.fr
}

Supplementary Material for this paper is available at: http://dx.doi.org/10.1387/ijdb.092856mm

Accepted: 24 September 2008. Published online: 2 March 2009. Edited by: Christine Mummery

ISSN: Online 1696-3547, Print 0214-6282

(C) 2009 UBC Press

Printed in Spain 
responsible for hormone production. The endocrine $\alpha, \beta, \delta$ and PP cells are secreting glucagon, insulin, somatostatin and pancreatic polypeptide, respectively. During embryonic development, the pancreas arises as dorsal and ventral buds from the definitive endoderm layer. This complex and regulated process involves the integration of signals from adjacent mesodermal tissues (reviewed in Kumar et al., 2003). Information provided by these signals activates a cascade of transcription factor expression (reviewed in Jensen, 2004; Bonal and Herrera, 2008) leading to differentiation and proliferation of pancreatic cells within the competent endoderm. Among known transcription factors, pancreatic duodenal homeobox 1 ( $\mathrm{Pdx}-1$ or Ipf1), a homeodomain protein, is involved in the development of pancreatic progenitor cells (Offield et al., 1996; $\mathrm{Gu}$ et al., 2002), and in insulin gene transcription and glucose response in mature $\beta$ cells (Holland et al., 2002). Gain-of-function studies indicate that neurogenin 3 (Ngn-3) and neurogenic differentiation 1 (NeuroD1), two bHLH factors, share the common ability to drive endocrine differentiation in the appropriate cell context (Apelqvist et al., 1999; Schwitzgebel et al., 2000) (Heremans et al., 2002) (Gasa et al., 2004). However, loss-of-function studies in mice revealed important differences in the roles of these two factors during endocrine differentiation. While Ngn-3 null animals lack all pancreatic endocrine cells (Gradwohl et al., 2000), NeuroD1 null mice die postnatally from severe diabetes due to a dramatic loss of insulin-producing $\beta$ cells, whereas the numbers of glucagon-producing $\alpha$ cells and somatostatin-producing $\delta$ cells are only

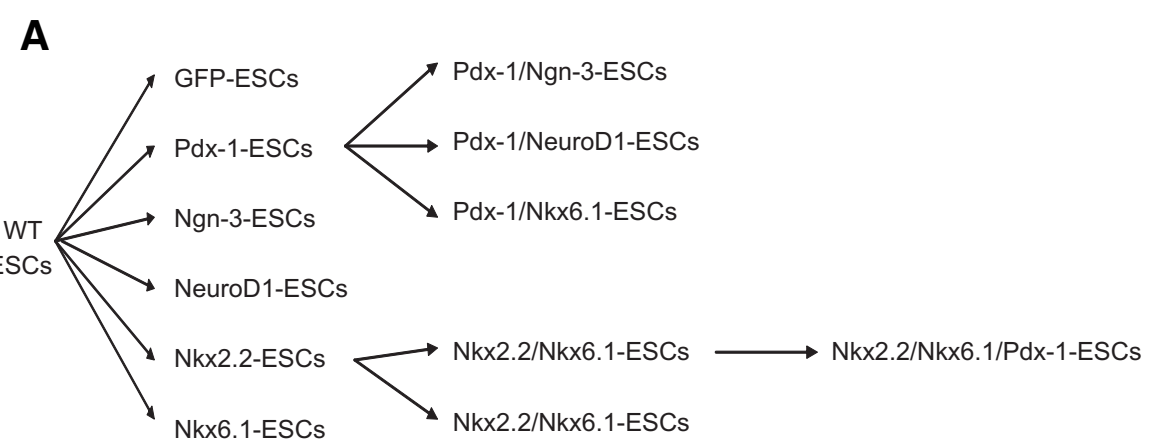

B

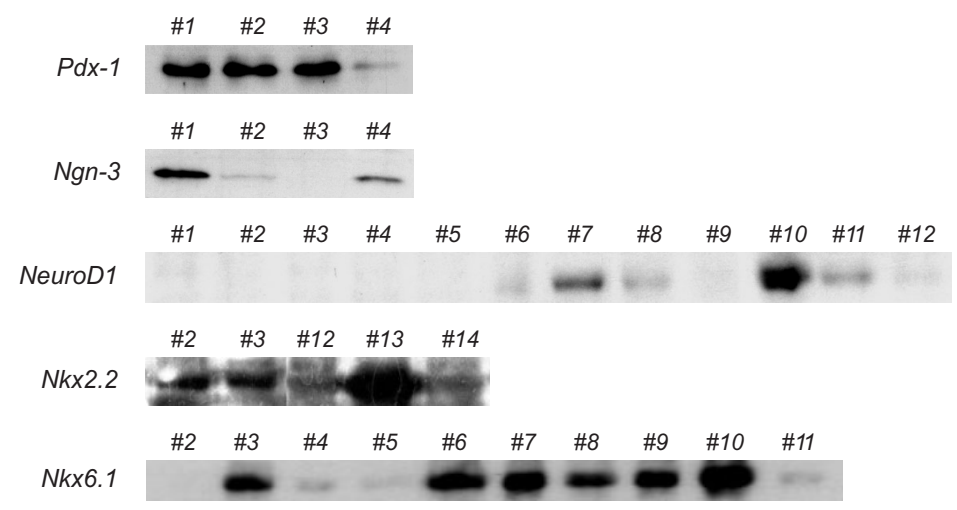

Fig. 1. Derivation of engineered ES cell lines stably expressing transcription factors Pdx1, Nkx2.2, Nkx6.1, NeuroD1, and Neurogenin-3 (Ngn-3), by means of lentiviral vector infection. (A) Schematic representation of the derivation of 12 ES cell lines expressing one, two and three transcription factors, from wild-type CGR8 ES cells (WT-ESC). (B) Immunoblotting analysis of ES cell lines expressing Pdx-1 (Pdx-1-ESC), Nkx2.2 (Nkx2.2-ESC), Nkx6.1 (Nkx6.1ESC), NeuroD1 (NeuroD1-ESC) and Ngn-3 (Ngn-3-ESC) transcription factors. modestly reduced (Naya et al., 1997). Lineage tracing experiments indicate that $\mathrm{Ngn}-3$ is a cell-autonomous determinant and a true marker of endocrine progenitor cells (Gu et al., 2002). Taken together, these data suggest that the transient expression of Ngn3 in the developing pancreas epithelium specifies which cells among the $\mathrm{Pdx}-1^{+}$pancreatic progenitor pool will follow an endocrine fate, while its downstream target NeuroD1 carries on the endocrine differentiation program initiated by Ngn-3 and participates in the maintenance of the differentiated phenotype of the mature islet cells. The differentiation of $\mathrm{Ngn}^{+}$endocrine progenitor cells through the $\beta$ cell pathway also requires the expression of other factors, such as Nkx2.2 (Sussel et al., 1998), Pax-4 (SosaPineda et al., 1997) and Nkx6.1 (Sander et al., 2000). NeuroD1 and $\mathrm{Nkx2.2}$ are also involved in the regulation of insulin gene transcription in mature $\beta$ cells (Naya et al., 1995) (Cissell et al., 2003).

Over the past few years, insulin-producing cells were derived from both mouse and human ES cells. Insulin-producing cells were obtained from ES cells by spontaneous differentiation (Assady et al., 2001; Kahan et al., 2003), lineage selection using pancreasspecific promoters (Soria et al., 2000; Leon-Quinto et al., 2004), directed differentiation using growth factor-based stepwise protocols (reviewed in Blyszczuk et al., 2004) or co-culture with embryonic pancreatic buds (Vaca et al., 2006) (Brolen et al., 2005). More recently, pancreatic-hormone-expressing endocrine cells (D'Amour et al., 2006; Kroon et al., 2008) and insulin-producing islet-like clusters (Jiang et al., 2007) were generated by using growth factors and signalling molecules stimulating the in vitro formation of definitive endoderm and the in vivo development of functional $\beta$-like cells from human ES cells. The overexpression of transcription factors, such as Pdx-1 (Lavon et al., 2006), Ngn-3 (Treff et al., 2006), Nkx2.2 (Shiroi et al., 2005) or Pax-4 (Blyszczuk et al., 2004), in ES cells has been shown to facilitate their differentiation into insulin-producing cells.

In the present work, we report the generation of mouse ES cell lines stably expressing Pdx-1, Ngn-3, NeuroD1, Nkx2.2 and Nkx6.1. We studied the capacity of these ES cell lines to differentiate into endocrine cells by using the threestep protocol via multilineage progenitors established by Blyszczuk et al. (2004), shown to result in the formation of functional glucoseresponsive insulin-producing cells (Boyd et al., 2008). The data presented show that NeuroD1 over-expression increases the expression of endocrine markers and facilitates differentiation of pancreatic precursors into insulin-producing cells.

\section{Results}

Generation of genetically modified ES cell lines stably expressing Pdx1, Ngn-3, NeuroD1, Nkx2.2, and Nkx6.1 transcription factors

ES cell lines that constitutively express the Pdx-1, Ngn-3, NeuroD1, Nkx2.2 and Nkx6.1 genes were engineered from CGR8 cells (here- 
after called WT-ESC). This was achieved by means of lentiviral vector infection and sub-cloning following a multi-step infection procedure to successively generate ES cell lines expressing one, two, and three transcription factors (Fig. 1A). An ES cell line expressing the Green Fluorescent Protein (GFP) was used as control (hereafter called GFP-ESC). In a first step, ES cell lines expressing one single transcription factor (Pdx1, Ngn-3, NeuroD1, Nkx6.1, and Nkx2.2) were generated. For differentiation studies, clones expressing transduced genes at the highest level were selected for subsequent infection steps: clone \#1 expressing $\mathrm{Pdx}$ 1 (hereafter called Pdx1-ESC), clone \#1 expressing Ngn-3 (hereafter called Ngn3-ESC), clone \#10 expressing NeuroD1 (hereafter called NeuroD1ESC), clone \#7 expressing Nkx6.1 (hereafter called Nkx6.1-ESC), clone \#13 expressing Nkx2.2 (hereafter called Nkx2.2-ESC) (Fig. 1B). In a second step, Pdx1-ESC was re-infected with the lentiviral vectors expressing Ngn-3, NeuroD1, and Nkx6.1, respectively. Clones (hereafter called Pdx1/Ngn3-ESC, Pdx1/ NeuroD1-ESC and Pdx1/Nkx6.1ESC) were selected for differentiation analysis. Similarly, Nkx2.2-ESC was re-infected with the lentiviral vector expressing Nkx6.1 to gener-

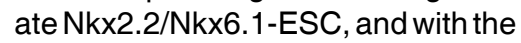
lentiviral vector expressing $\mathrm{Pdx}-1$ to

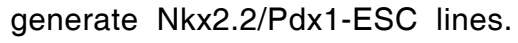
The Nkx2.2/Nkx6.1-ESC line was subsequently re-infected with the lentiviral vector expressing $\mathrm{Pdx}-1$ to generate Nkx2.2/Nkx6.1/Pdx-1-ESC.

Transgene expression was analysed by immunofluorescence in undifferentiated ES cells using specific antibodies (Fig. 2). Immunostaining was specific and localized in the nucleus in all clones analysed. To determine if transgene expression compromised self-renewal, all clones were analysed for expression of the pluripotency markers Oct-4 and Nanog by flow cytometry. This analysis revealed differences in the percentage of cells expressing Oct-4 and Nanog, ranging from $40 \%$ to $96 \%$ in transgenic ES cell lines, compared to $80 \%$ in control ES cells (Fig. 3 and Supplementary Fig. 1). Therefore, constitutive expression of most transgenes obviously affects expression levels of the pluripotency-associated genes Oct4 and Nanog, which may lead to an increased rate of spontaneous differentiation. However, all transgenic ES cell lines could be propagated for several months in culture and formed embryoid bodies (EBs) upon growth in suspension (see next sections),
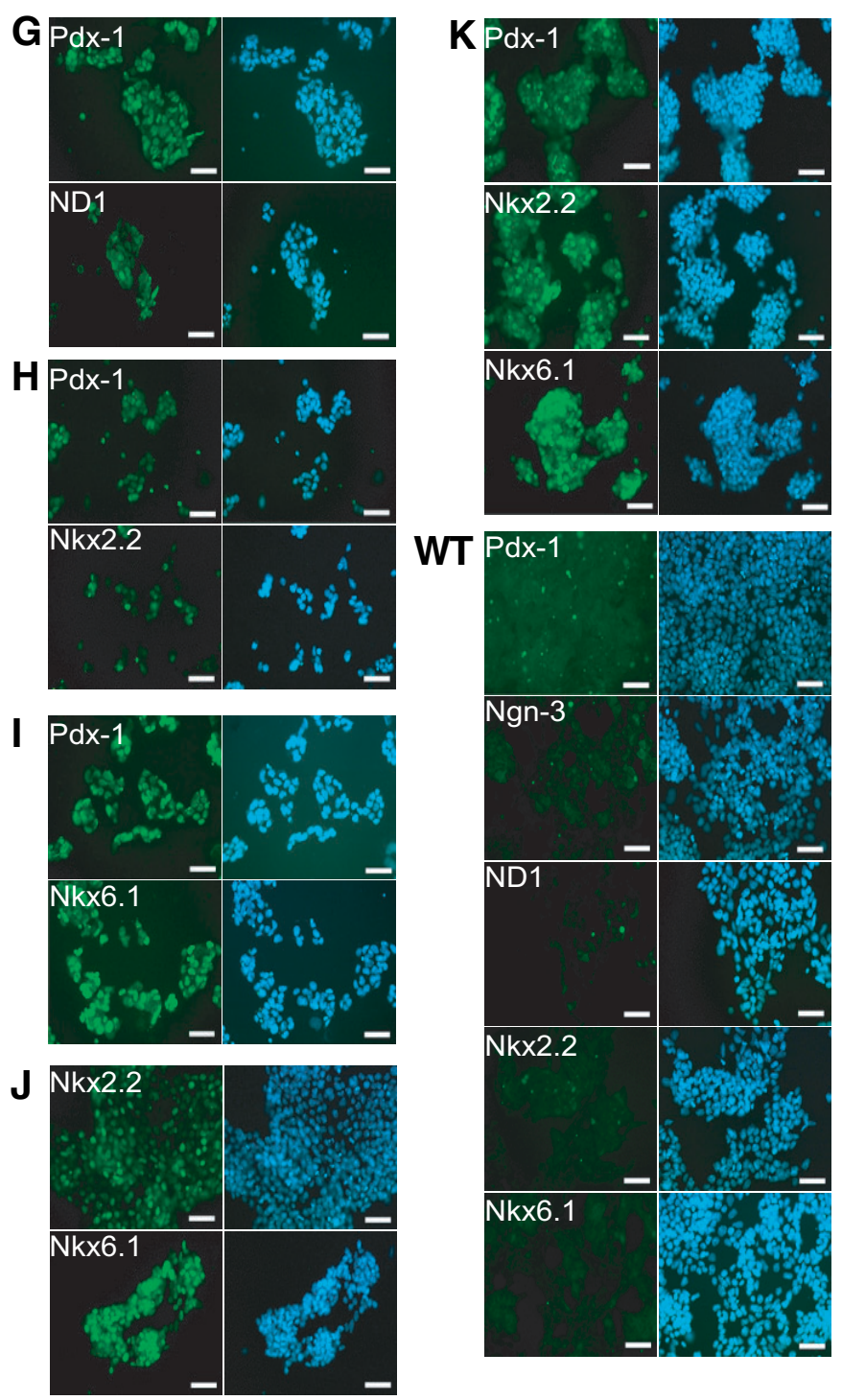

Fig. 2. Expression of transcription factors in engineered ES cell lines. Immunofluorescence labelling of $E S$ cell lines stably expressing Pdx-1 (A), Ngn-3 (B), NeuroD1 (C), Nkx2.2 (D), Nkx6.1 (E), Pdx-1+Ngn3 (F), $P d x-1+N e u r o D 1 \quad(G), P d x-1+N k x 2.2$ (H), $P d x-1+N k x 6.1$ (I), $N k x 2.2+N k x 6.1$ (J), and $P d x-$ $1+N k \times 2.2+N k \times 6.1$ (K). Cells are labelled with FITC-conjugated antibodies (green) and counterstained with Hoechst to label nuclei. WT-ESC (WT) are shown as negative controls. Scale bar, $200 \mathrm{~mm}$.

indicating that they retained strong self-renewal capabilities.

\section{NeuroD1-ES cells exhibit strongly increased expression of endocrine markers after differentiation}

ES cell lines were induced to differentiate via EBs, as described previously (Blyszczuk et al., 2004; Schroeder et al., 2006; Boyd et al., 2008). Expression of the endocrine markers insulin1 (ins-1), insulin-2 (ins-2), glucagon (Glc) and somatostin (Sst) was analysed at differentiation stage $5+28 \mathrm{~d}$. During mouse embryonic development, Ins- 1 is only expressed in $\beta$-cells, while ins2 is expressed both in $\beta$-cells and in the developing brain (Deltour et al., 1993). Glc and Sst expression characterizes $\alpha$ and $\delta$ cells of the Langerhans islets, respectively. Nkx2.2-ESC, Pdx-1/Nkx6.1ESC, Pdx-1/Nkx2.2/Nkx6.1/NeuroD1-ESC showed a strong increase in Glc expression after differentiation, when compared to 


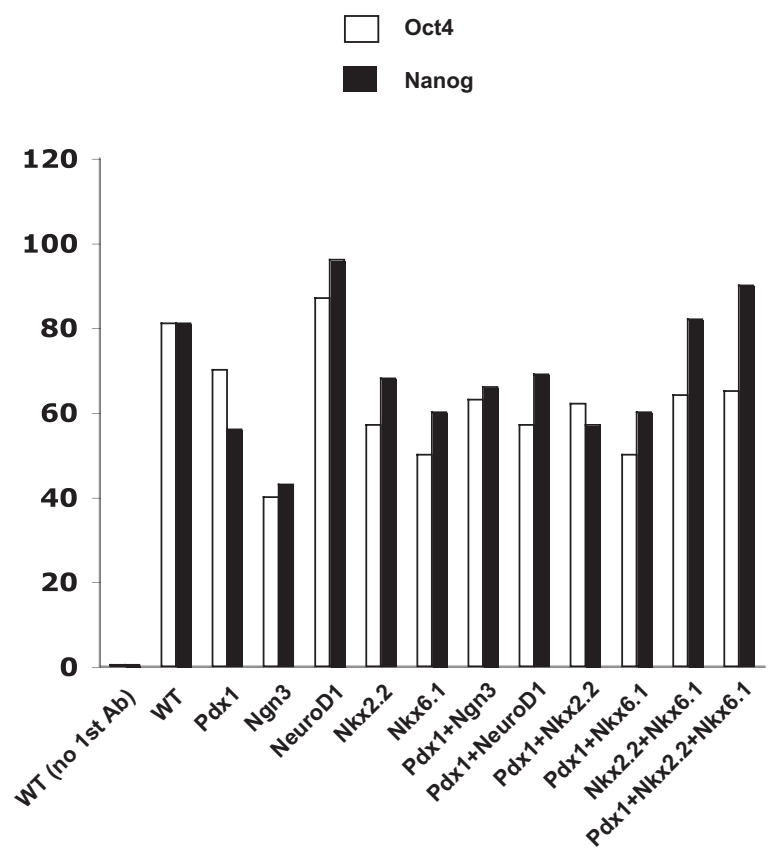

Fig. 3. Expression of pluripotency factors Oct-4 and Nanog in engineered ES cell lines. Histograms showing the percentage of $\mathrm{Oct}-4^{+}$and Nanog ${ }^{+}$cells after immunolabelling with specific antibodies and analysis by flow cytometry.

the GFP control line, whereas expression of the other endocrine markers analysed were not different to the control (Fig. 4A). Pdx-1/Nkx2.2-ESC showed a strong increase in ins-2 expression at $5+28 d$ of differentiation. Pdx-1/Ngn-3-ESC showed an increase in both ins-1 and ins-2 expression, but Glc expression remained below detection level. In contrast, Ngn3-ESC and NeuroD1-ESC showed a strong increase in the expression of all four endocrine markers. NeuroD1-ESC showed the highest increase in Glc level.

Strong induction of GIc, Sst, Ins-1 and Ins-2 expression at differentiation stage $5+28 d$ in NeuroD1-ESC was confirmed in an independent experiment (Fig. 4B). When compared to WTESC, NeuroD1-ESC showed a significant increase in Glc expression ( $24+/-2.4$ fold, $p<0.01, n=3)$, in ins- 1 expression (13 $+/-2.7$ fold, $\mathrm{p}<0.05, \mathrm{n}=3)$, and in Sst expression $(10+/-0.2$ fold, $\mathrm{p}<0.001, \mathrm{n}=3)$. Ins-2 expression was moderately increased $(6+/-1.2$ fold, $p<0.2, n=3)$.

NeuroD1-ESC also showed a strong increase in the expression of the endocrine transcription factors Pdx-1, Nkx6.1, Pax6 and Isl-1 (Fig. 4C). Nkx2.2 is the only factor analysed which did not show elevated expression. Expression of the $\beta$-cellspecific glucose transporter-2 (Glut-2) and glucokinase (GK) genes was also strongly up-regulated in NeuroD1-ESC compared to WT-ESC. Of note, only low transcript levels of the neuronal genes $\mathrm{Nfm}$ (neurofilament heavy chain) and Syn (synaptophysin) were seen in NeuroD1-ESC. Nfm and Syp expression disappeared after differentiation under reduced glucose conditions (data not shown).

Together, these results show that stable expression of NeuroD1 in ES cells dramatically increases the expression of endocrine and $\beta$-cell markers upon differentiation.

\section{NeuroD1 over-expression increases proliferation of nestin ${ }^{+}$ precursors and accelerates formation of pancreatic-com- mitted progenitors}

NeuroD1-ESC showed increased cell proliferation during in vitro differentiation relative to control, evidenced by a rapid exhaustion of medium and a dramatic overgrowth at stage $5+28 d$. We asked if the population of precursor cells exhibited an increased proliferation rate. To this aim, a proliferation assay based on BrdU incorporation was performed during WTESC and NeuroD1-ESC differentiation. Nestin ${ }^{+}$progenitors in the S-phase of the cell cycle $\left(\mathrm{BrdU}^{+}\right)$were detected by doubleimmunofluorescence (Fig. 5A). No difference in the frequency of nestin ${ }^{+} \mathrm{BrdU}^{+}$cells was observed between WT-ESC and NeuroD1-ESC until differentiation stage $5+7 d$. By contrast, from differentiation stage $5+9 d$ onwards, when multilineage progenitors $(5+9 d)$ and committed precursors $(5+12,5+16 d)$ form (see Blyszczuk et al., 2004), a larger fraction of nestin ${ }^{+}$ precursors derived from NeuroD1-ESC were $\mathrm{BrdU}^{+}(5+9 \mathrm{~d}$ : 1.6 +/- 0.2 fold, $\mathrm{p}<0.05, \mathrm{n}=4 ; 5+12 \mathrm{~d}: 1.5+/-0.3$ fold, $\mathrm{p}<0.05, \mathrm{n}$ $=4 ; 5+16 \mathrm{~d}: 1.5+/-0.2$ fold, $\mathrm{p}<0.05, \mathrm{n}=4)$. These results indicate that NeuroD1-ESC-derived nestin ${ }^{+}$progenitors exhibit a higher proliferation rate.

At early stage $5+9 d$, pancreatic progenitors can be distinguished by the co-expression of neurofilament nestin and cytokeratin 19 (CK19). By contrast, at stage 5+16d, nestin is coexpressed with IsI-1, a LIM homeodomain protein that controls cell-fate decision required for the differentiation of islet cells (Ahlgren et al., 1997). Double labelling of nestin and Isl-1 has been used to characterize endocrine-committed pancreatic progenitors from stage $5+16$ d onwards (Blyszczuk et al., 2004). Immunostaining of nestin ${ }^{+} / \mathrm{Isl}-1^{+}$cells was performed during differentiation of WT-ESC and NeuroD1-ESC to identify endocrine-committed progenitors. In WT-ESC, nestin+/Isl-1+ clusters were first detected at stage $5+16 \mathrm{~d}$ as previously described (data not shown, see (Blyszczuk et al., 2004)). Some occasional nestin $/ / \mathrm{Isl}-1^{+}$cells were detectable as early as stage $5+9 d$, but they were dispersed and did not form clusters (Fig. $5 B$ ). This contrasted with NeuroD1-ESC that showed numerous nestin ${ }^{+} / \mathrm{Isl}-1^{+}$positive cells organized in clusters as early as stage $5+9 \mathrm{~d}$. These results suggest that in NeuroD1-ESC the formation of nestin ${ }^{+} / \mathrm{Isl}-1^{+}$endocrine-committed progenitors is accelerated.

\section{NeuroD1 overexpression accelerates the formation of in- sulin-producing clusters}

NeuroD1-ESC showed an elevated expression of $\beta$-cell markers in differentiated cells at $5+28 d$ (Fig. 4). We then asked if the yield of $\mathrm{C}$-peptide+/insulin ${ }^{+}$cells was increased. Double immunostaining for insulin and $\mathrm{C}$-peptide was performed at the differentiation stage of $5+16 d$ (Fig. 5). NeuroD1-ESC formed 3.4-fold more C-peptide ${ }^{+} /$insulin $^{+}$clusters than control WT-ESC (Fig. 6A). Moreover, NeuroD1-ESC-derived clusters contained a high number of insulin-positive cells (Fig. 6B). In contrast, WT-ESC-derived clusters displayed occasional insulin ${ }^{+}$cells, which seldom formed typical clusters at stage $5+16 \mathrm{~d}$. With WTESC, the typical clusters were only observed at the terminal stage of 5+28d (see Blyszczuk et al., 2004; Schroeder et al., 2006). Together, these observations indicate that in NeuroD1ESC the formation of C-peptide ${ }^{+} /$ins $^{+}$clusters is accelerated. 


\section{Discussion}

The aim of this study was to examine the ability of engineered mouse ES cells to differentiate into pancreatic endocrine cells following a differentiation protocol previously optimized for differentiation into insulin-producing cells (Blyszczuk et al., 2004; Schroeder et al., 2006). This protocol was confirmed to be efficient in generating functional glucose-responsive insulinproducing cells (Boyd et al., 2008) and to induce the generation of other cell types of the islet of Langerhans, such as $\alpha$-and $\delta$-cells (Schroeder et al., 2006; Boyd et al., 2008). Following this protocol,
A
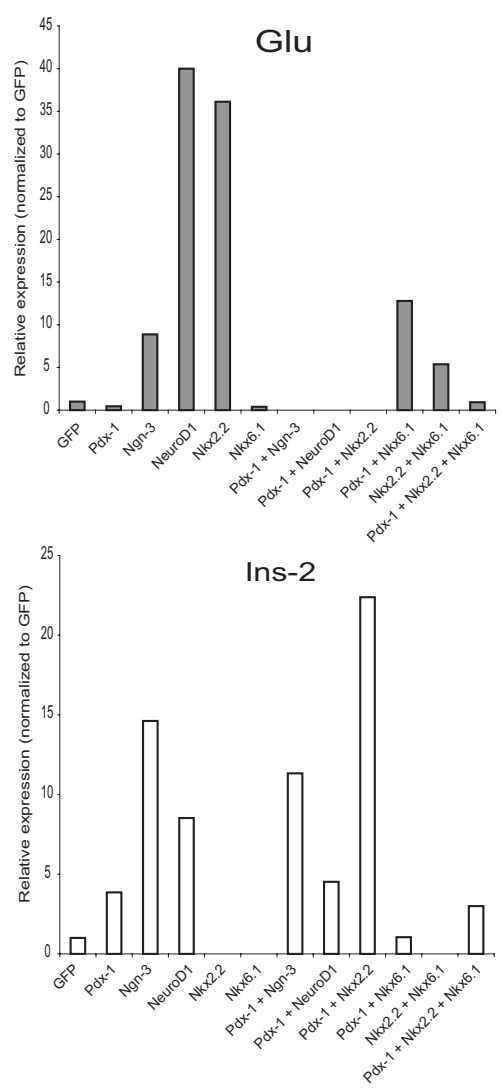

B
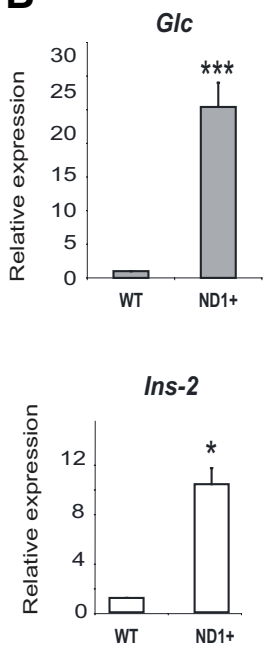

5
$\frac{0}{0}$
0
0
0
$\frac{0}{x}$
0
0
2
$\frac{0}{0}$
$\frac{0}{0}$
$\square$

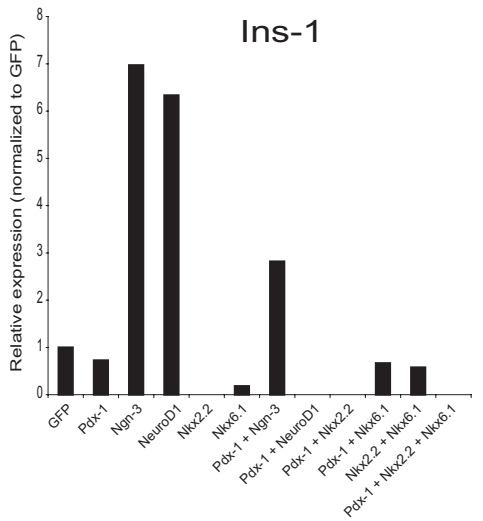

Sst

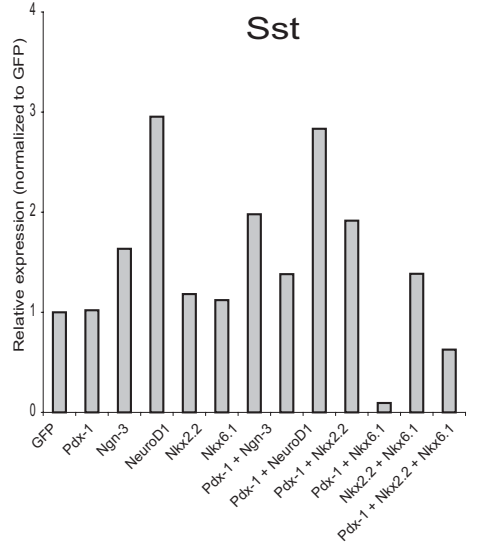

C
Ins-1
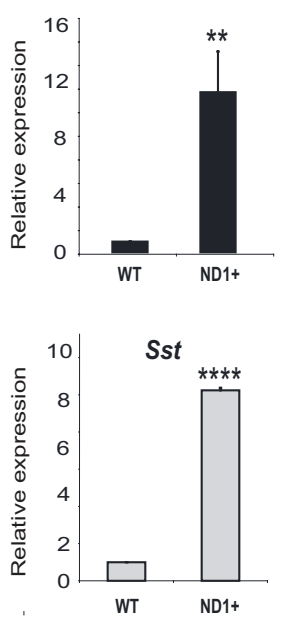

a fraction of the cell population differentiates into pancreatic precursor-like cells, evidenced by the co-expression of the neurofilament nestin and the endocrine-specific transcription factor Isl-1. At a later stage, they further differentiate into insulinproducing cells organized in clusters. The fraction of cells adopting a $\beta$-like phenotype can be significantly increased by overexpressing the transcription factor Pax-4 (Blyszczuk et al., 2004; Schroeder et al., 2006), which suggests that expression of endogenous Pax-4 is rate-limiting for $\beta$-cell differentiation.

The rationale of our experimental approach relies on the assumption that the differentiation protocol does not allow efficient activation of endocrine differentiation programs because some critical transcription factors are present in limiting amounts. Forced expression of these factors would then facilitate the activation of an endocrine differentiation program by providing additional transcriptional activities. To this aim, a number of ES cell lines were engineered to over-express transcription factors involved in the determination of the pancreatic epithelium (Pdx-1, Jonsson et al., 1994; Gu et al., 2002), of the endocrine lineage (Ngn-3, Gradwohl et al., 2000), and of the $\beta$-cell lineage (NeuroD1, Nkx2.2, Nkx6.1, Naya et al., 1997; Sussel et al., 1998; Sander et al., 2000). Because endocrine differentiation is known to result from the coordinated action of several transcription factors (Jensen, 2004) (Murtaugh, 2007), we sought to generate ES cell lines expressing multiple factors to further enhance the yield of endocrine differentiation. Real-time PCR analysis of the $\alpha, \beta$ and $\delta$ cell markers, Ins, Glc and Sst, respectively, revealed that each cell line showed a specific pattern of gene expression. ES cell lines over-expressing Nkx2.2 and Nkx6.1, either alone or in combination with $\mathrm{Pdx} 1$, showed no increase in insulin gene expression compared to control cells, despite Nkx2.2 and Nkx6.1 were previously shown to regulate $\beta$-cell differentiation (Sussel et al., 1998; Sander et al., 2000). Similarly, over-expression of $\mathrm{Pdx}-1$ had no effect on the yield of $\beta$-cell differentiation despite $\mathrm{Pdx}-1$ is known both to be required in vivo for the development of all pancreatic cell types (Jonsson et al., 1994) (Gu et al., 2002), and to be a critical regulator of ins gene expression in mature $\beta$-cells (Ahlgren et al., 1998; Holland et al., 2002). It was previously reported that over-expression of $\mathrm{Pdx}-1$ had only little effect on the yield of $\beta$-cell differentiation from mouse (Blyszczuk et al., 2003; Miyazaki et al., 2004)

Fig. 4. Expression of endocrine markers ins-1, ins-2, GIc and $\mathbf{S} s t$ in the engineered ES cell lines. (A,B) Real-time $P C R$ analysis of ins-1, ins-2, Glc and Sst mRNA levels at differentiation stage $5+28 d$. mRNA levels measured in ES cell lines expressing transcription factors were subsequently normalized to MRNA levels measured in the GFP (A) or WT (B) control lines. (B) Histograms represent means and standard errors calculated in three replicates (statistical significance was determined with the unpaired two-sided test. $\left.p<0.2={ }^{*} ; p<0.01={ }^{* *} ; p<0.001={ }^{* *}\right)$. (C) Semi-quantitative RT-PCR analysis of endocrine transcription factors, $\beta$-cell and neuronal marker expression in NeuroD1-ESC and WTESC. 
(Takayama et al., 2008) and human ESCs (Lavon et al., 2006). Together, these observations indicate that none of the three transcription factors $\mathrm{Pdx}-1, \mathrm{Nkx2.2}$, and Nkx6.1 is rate limiting during $\beta$ cell differentiation induced in our protocol. By contrast, over-expression of Ngn-3 and NeuroD1 increased the expression of $\alpha, \beta$ and $\delta$ cell markers, NeuroD1 showing the strongest effect of both. This result is in agreement with gain-of-function studies which revealed that Ngn-3 and NeuroD1 induced endocrine differentiation when expressed ectopically in vitro (Heremans et al., 2002) (Gasa et al., 2004) (Treff etal., 2006) or in vivo (Apelqvist etal., 1999; Schwitzgebel et al., 2000; Grapin-Botton et al., 2001; Kojima et al., 2003; Kaneto et al., 2005). Surprisingly, ES cell lines over-expressing Pdx-1 and NeuroD1 showed no increase in endocrine markers. We can speculate that forced expression of $\mathrm{Pdx}-1$ prevents ectopic NeuroD1 from properly activating the transcription of endocrine genes in differentiating cells. Alternatively, it may be inferred that the Pdx-1/NeuroD1-ESC expresses NeuroD1 at a lower level than the NeuroD1-ESC that would make NeuroD1-associated transcriptional activity unable to activate an endocrine differentiation program in $\mathrm{Pdx}-1 /$ NeuroD1-ESC.

\section{A}

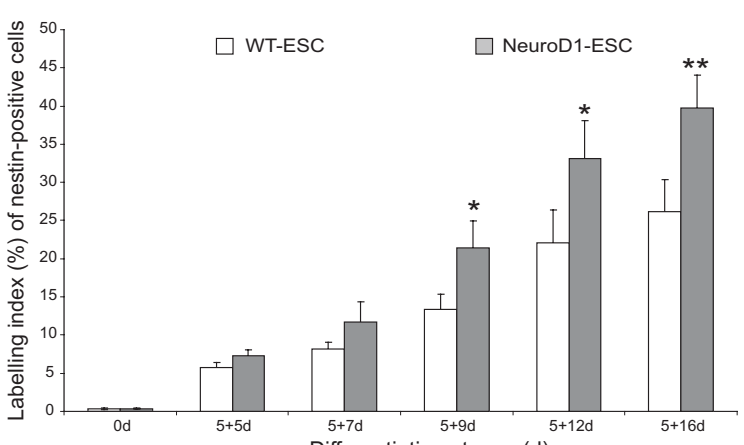

Differentiation stages $(d)$
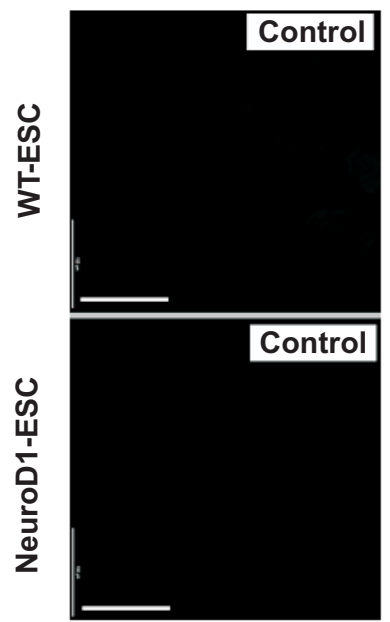
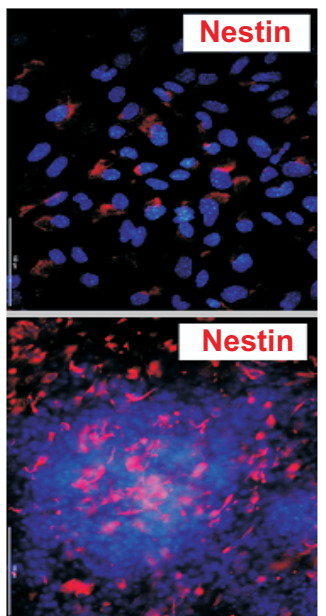
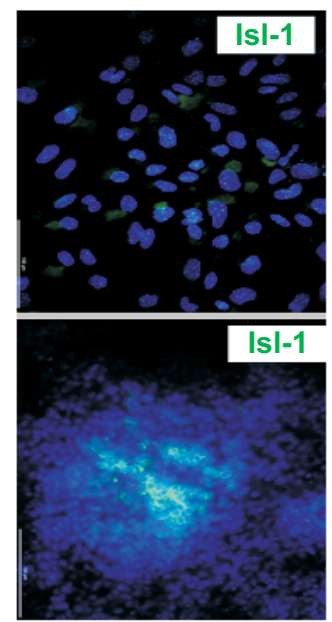

In the second part of this work, we focused our study on NeuroD1-ESC that showed a vastly improved capacity for endocrine differentiation compared to all other engineered ES cell lines, including differentiation to the $\beta$-cell lineage. The influence of NeuroD1 on $\beta$-cell differentiation was evidenced by a strong increase in the expression of genes encoding Pdx-1, Nkx6.1, Pax6 , Isl-1, the glucose receptor Glut-2 and GK. These observations are in line with - and extend - the previous observations of Saitoh et al. who showed that forced expression of NeuroD1 via adenoviral vector infection restores the expression of insulin lost upon passaging of Pdx-1-expressing ES cells (Saitoh et al., 2007). Together, these observations indicate that NeuroD1 is a ratelimiting factor during in vitro differentiation of ES cells into $\beta$-like cells.

How enforced NeuroD1 expression stimulates endocrine and $\beta$-cell differentiation is not yet clear. First, we showed that NeuroD1ESC generates more nestin ${ }^{+} / \mathrm{IsI}-1^{+}$precursors than WT-ESC at the early differentiation stage $5+9 \mathrm{~d}$. This suggests that, at this multilineage progenitor stage, more cells representing progenitors of all three primary germ layers, including multilineage pancreatic progenitors, are formed. This might result from an increased proliferation rate, as it was observed in the whole nestin ${ }^{+}$cell population. However, whether the proliferation of the definitive endocrine progenitor population is accelerated remains to be determined. Second, NeuroD1-ESC was found to produce insulin $^{+} /$C-peptide ${ }^{+}$clusters as early as stage $5+16 \mathrm{~d}$, therefore approximately 12 days earlier than WT-ESC. Premature differentiation into insulin ${ }^{+} / \mathrm{C}$-peptide ${ }^{+}$cells might result from the premature differentiation of nestin $/ / \mid \mathrm{sl}-1^{+}$multilineage precursors at stage 5+9d. Alternatively, it can be speculated that over-expression of NeuroD1 increases the proliferation rate of differentiating $\beta$-like cells. This hypothesis is supported by the observation that homozygous NeuroD1 null mice have a strong reduction in the number of insulin-producing $\beta$-cells. Islet morphogenesis appeared to be arrested between E14.5 and E17.5, a period characterized by major expansion of the $\beta$-cell population (Naya et al., 1997). Mentionable is the dramatic growth rate that characterizes NeuroD1-ESC cultures at final stages of differentiation (beyond stage $5+16 d)$. It results in massive cell overgrowth paralleled by high metabolic activity and subsequent failure to analyse insulin $^{+} /$C-peptide ${ }^{+}$clusters at stage $5+28 d$. However, the elevation of $\beta$-cell marker expression (Glut-2, GK, ins-1 and ins-2) at 5+28d indicates that NeuroD1 over-expression increased the yield of $\beta$-like cell differentiation at late stages. This could result either from an increase in the fraction of cells adopting a $\beta$ like phenotype, and acceleration of the differentiation process into glucose-producing
Fig. 5. Differentiation of NeuroD1-ESC into nestin ${ }^{+} / \mathbf{I s | 1 ^ { + }}$ progenitors and analysis of proliferation. (A) Proliferation analysis of nestin ${ }^{+}$cells in undifferentiated (Od) NeuroD1-ESC and WT-ESC, and at differentiation stages of $5+5 d, 5+7 d, 5+9 d, 5+12 d$ and $5+16 d$, revealed by double-immunofluorescence for expression of nestin and incorporation of BrdU. Histograms represent means and standard errors calculated in four replicates. Statistical significance was tested by the Anova test with $85 \%$ of confidence interval $\left(p<0.05=* ; p<0.01={ }^{*}\right)$. (B) Double-immunofluorescence analysis of nestin (red)- and Isl-1 (green)-positive cells, performed at differentiation stage of 5+9d of NeuroD1-ESC and WT-ESC. Nuclei are labelled with Hoechst. Scale bar, $100 \mathrm{~mm}$. 
A

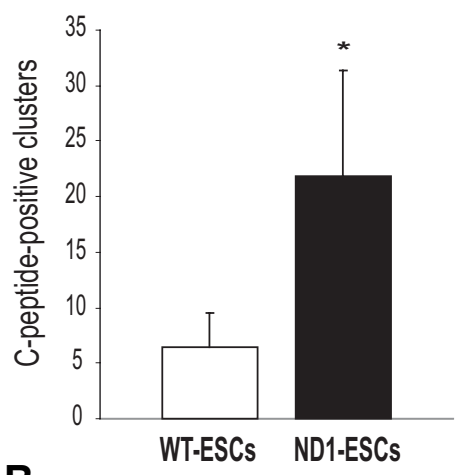

$5+16 d$ WT-ESCs
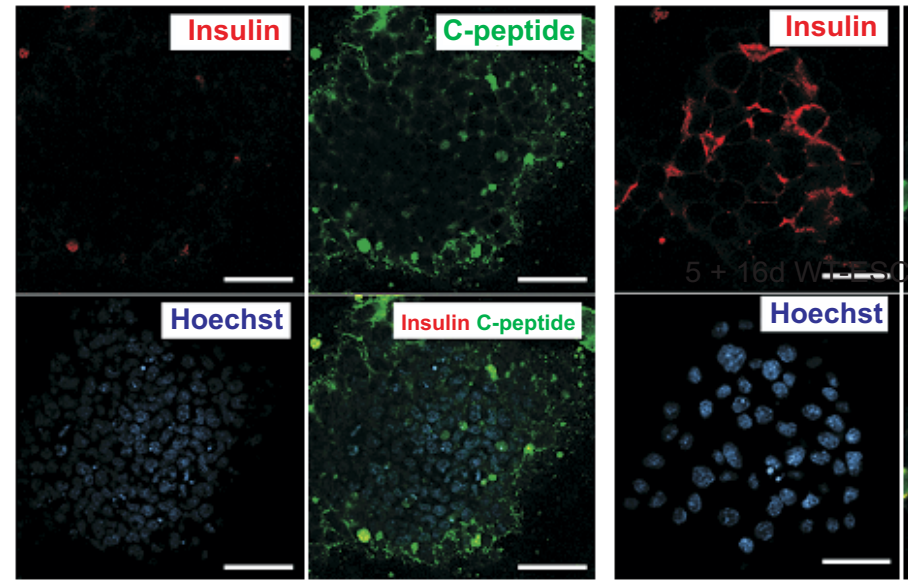

cells. Further modification of the differentiation protocol is needed to study the maturation of insulin ${ }^{+}$C-peptide ${ }^{+}$clusters at terminal stages in vivo (Kroon et al., 2008), in particular measure insulin release upon glucose stimulation.

\section{Materials \& Methods}

\section{Plasmid construction and lentiviral vector production}

$p E F s$-eGFP harbors the sequence encoding the enhanced green fluorescent protein driven off the minimal version of the human EF1 $\alpha$ promoter (EFs) (Fluckiger et al. 2006). pEFs-Pdx-1, pEFs-Ngn-3, pEFsNeuroD1, $p E F s-N k \times 2.2$ and $p E F s-N k \times 6.1$ lentiviral vectors were generated from $p E F s$-eGFP by replacing the fragment containing the eGFP sequence by the full-length cDNAs encoding mouse Pdx-1 (5'-Sall(blunt)/ Bglll-3' fragment from pZL1-Pdx1), HA-tagged mouse Ngn-3 (5'HindllI(blunt)/EcoRV-3' fragment from pcDNAl/Amp/HA-Ngn-3), Myctagged mouse NeuroD1 (5'-BamHI/Xhol-3' fragment from pCS2 ${ }^{+} \mathrm{MT}$ NeuroD1), hamster Nkx2.2 (5'-Avrll(blunt)/Xhol-3' fragment from pBAT12shNkx2.2), and hamster Nkx6.1 (5'-Xhol(blunt)/Xbal(blunt)-3' fragment from pBAT12-Nkx6.1 (Rudnick et al., 1994)). The method for producing SIV-based vectors in 293T cells is fully described elsewhere (Negre et al., 2000) (Mangeot et al., 2000). Briefly, 293T cells were transfected with a mixture of DNAs containing $10 \mu \mathrm{g}$ of the $p G R e v$ plasmid encoding the vesicular stomatitis virus glycoprotein (VSV-G) envelope, $10 \mu \mathrm{g}$ of the $p S I V 3^{+}$plasmid encoding the gag, pol, tat and rev proteins, and $13 \mu \mathrm{g}$ of the $p E F s$ plasmid encoding the cDNA of interest, using the calcium phosphate precipitation technique. The following day, cells were refed with $7 \mathrm{ml}$ of DMEM and further cultured for 24 hours. The supernatant was then collected, cleared by centrifugation (3000 RPM, 15 minutes) and passed through a $0.8 \mu \mathrm{m}$ filter.

\section{ES cell culture and gene transduction}

Undifferentiated murine ES cells from the feeder-independent CGR8 cell line were routinely cultured in Glasgow's modified Eagle's medium (GMEM; Invitrogen, Carlsbad, CA, http:/ /www.invitrogen.com) supplemented with $10 \%$ foetal calf serum (FCS; Biowest, Nuaillé, France, www.biowest.net), 2 mM L-glutamine (Invitrogen), $100 \mu \mathrm{M}$ non-essential amino acids (Invitrogen), $1 \mathrm{mM}$ sodium pyruvate (Invitrogen), $100 \mathrm{U} /$ $\mathrm{ml}$ penicillin-100 $\mu \mathrm{g} / \mathrm{ml}$ streptomycin (Invitrogen), $100 \mu \mathrm{M} \beta$-mercaptoethanol (Sigma, St. Louis, http://www/sigmaaldrich.com) and $1000 \mathrm{U} / \mathrm{ml}$ of Leukemia Inhibitory Factor (LIF) as previously described (Savatier et al., 1996). 105 CGR8 ES cells were infected for 5 hours with $1 \mathrm{ml}$ of lentiviral supernatant supplemented with LIF, and further cultured for 48 hours. The infected cells were sub-cloned in 96 well plates. Individual colonies were amplified and transgene expression analysed by immunoblotting.

\section{In vitro differentiation of ES cells}

The protocol used for in vitro differentiation of ES cell lines was previously described (Blyszczuk et al., 2004; Schroeder et al., 2006). Differentiation of ES cell lines was induced by the formation of embryoid bodies (EB) using the "hanging drop" method (600 ESCs/EB) in ES cell medium without LIF. After 2 days, EBs were collected and further grown in suspension for 3 days. At day 5 of differentiation $(5 d)$, EBs were plated on gelatine-coated 6-well plates (10 EBs/well) in "Differentiation Medium I" (see Schroeder et al., 2006) and further cultured for 9 days. At day 14 of differentiation $(5+9 d)$, EB outgrowths were cultured in "Differentiation Medium II" supplemented with 15\% FCS for 24 hours. At day 15 of differentiation $(5+10 d)$, cells were refed with "Differentiation Medium II" without FCS until 33 days of differentiation $(5+28 d)$.

For immunofluorescence analysis EBs (5d) were plated on gelatinecoated $60 \mathrm{~mm}$ dishes (20 EBs/dish). At the stage of $5+9 \mathrm{~d}$, EB outgrowths were dissociated by incubation in a solution of $0.1 \%$ trypsin (Invitrogen): $0.08 \%$ EDTA (Sigma) in PBS (1:1) for 90 seconds at room temperature, collected by centrifugation (300 rpm, $3 \mathrm{~min}$ ), and replated onto poly-Lornithine/laminin-coated cover slips placed in $60 \mathrm{~mm}$ dishes.

\section{Semi-quantitative and real-time PCR analysis}

Total RNA was extracted using RNAeasy kits with on-column DNAse digestion (Qiagen, http://www.qiagen.com). Reverse transcription was performed using M-MLV Reverse Transcriptase (Promega Corp., Madison, WI, http://www.promega.com) and Random Primers (MWG-Biotech AG, Ebersberg, Germany, http://www.mwg-biotech.com), according to the manufacturer's recommendations. PCR reactions were performed with a Perkin-Elmer thermal cycler, operating on a regimen of $94^{\circ} \mathrm{C}$ for 30 sec, 55 to $62^{\circ} \mathrm{C}$ (according to primers) for $30 \mathrm{sec}$ and $72^{\circ} \mathrm{C}$ for $60 \mathrm{sec}$. Primers, annealing temperatures and number of cycles are:

$P d x-1$ : 5'-ACCATGAACAGTGAGGAGCA-3' (forward),

5'-TCCTCTTGTTTTCCTCGGGT-3' (reverse), 58 ${ }^{\circ} \mathrm{C}$, 35 cycles; Nkx2.2: 5'-AACCGTGCCACGCGCTCAAA-3' (forward),

5'-AGGGCCTAAGGCCTCCAGTCT-3' (reverse), 58 ${ }^{\circ} \mathrm{C}, 34$ cycles; Nkx6.1: 5'-TCTTCTGGCCCGGGGTGATG-3' (forward),

5'-AGCCGCGTGCTTCTTCCTCCA-3' (reverse), 62 ${ }^{\circ} \mathrm{C}$, 34 cycles; NeuroD1: 5'-CTTGGCCAAGAACTACATCTGG-3' (forward),

5'-GGAGTAGGGATGCACCGGGAA-3' (reverse), 58 ${ }^{\circ} \mathrm{C}$, 34 cycles; Pax-6: 5'-GCTTCATCCGAGTCTTCTCCGTTAG-3' (forward), 
5'-CCATCTTGCTTGGGAAATCC G-3' (reverse), $60^{\circ} \mathrm{C}$, 30 cycles; Isl-1: 5-AGATATGGGAGACATGGGCGAT-3' (forward),

5'-ACACAGCGGAAACACTCGATG-3' (reverse), $55^{\circ} \mathrm{C}, 35$ cycles; Glut-2: 5'-CGG TGGGACTTGTGCTGCTGG-3' (forward),

5'-CTCTGAAGACGCCAGGAATTCCAT-3', 60 $\mathrm{C}, 40$ cycles;

GK: 5'-TGGATGACAGAGCCAGGATGG-3' (forward),

5'-ACTTCTGAGCCTTCTGGGGTG-3' (reverse), 60 $\mathrm{C}$, 35 cycles; Nfm: 5'-TATTGTGACTGAGGGCTG-3' (forward),

5'-GAGGCACTAAGGAG-3' (reverse), $60^{\circ} \mathrm{C}, 45$ cycles; Syp: 5'-TACCGAGAGAACAACAAAGGGC -3' (forward),

5'-GCCTGTCTCCTTGAACACGAAC-3' (reverse), $60^{\circ} \mathrm{C}, 45$ cycles. $\beta$-actin: 5'-TGAAACAACATACAATTCCATCATGAAGTGTGA-3' (forward),

5'-AGGAGCGATAA TCTTGATCTTCATGGTGCT-3' (reverse), $58^{\circ} \mathrm{C}, 20$ cycles.

Quantitative PCR was performed using the LightCycler ${ }^{\mathrm{TM}} 1.5$ system and the LightCycler Fast Start DNA Master SYBR Green I kit (Roche Applied Science, Indianapolis, http://www.roche-applied-science.com) according to the manufacturer's instructions. Reactions were carried out in a total volume of $20 \mu \mathrm{l}$, comprising $0.4 \mu \mathrm{M}$ of each primer, $4 \mathrm{mM} \mathrm{MgCl}_{2}$, $2 \mu \mathrm{l} \mathrm{SYBR}$ Green, and $5 \mu \mathrm{l}$ of diluted cDNA. Primers are:

ins-1: 5'-CCAGCTATAATCAGAGACCA-3' (forward) and

5'-GTGTAGAAGAAGCCACGCT-3' (reverse);

ins-2: 5'-AGCAGGAAGCCTATCTTCCA-3' (forward) and

5'-GGACATGGGTGTGTAGAAGAA-3' (reverse);

Glc: 5'-CAGAGGAGAACCCCAGATCA-3' (forward) and

5'-TGACGTTTGGCAATGTTGTT-3' (reverse);

sst: 5'-GAGGCAAGGAAGATGCTGTC-3' (forward) and

5'-CAGCAGCTCTGCCAAGAAGT-3' (reverse).

Amplification and online monitoring was performed using the LightCycler $^{\mathrm{TM}} 1.5$ system. Following 40 amplification cycles, melt-curve analyses were performed to verify only the desired PCR product had been amplified. PCR efficiency of both the target and reference genes was calculated from the derived slopes of standard curves by the LightCycler software (Roche Molecular Biochemicals LightCycler Software, Version 4.0). These PCR efficiency values were used to calculate the relative quantification values for calibrator-normalised target gene expression by the LightCycler relative quantification software (Version 4.0). In all cases target genes were normalised to $\beta$-actin.

\section{Immunofluorescence analysis}

ES cells and differentiated cells growing on cover slips were fixed with $4 \%$ paraformaldehyde (PFA) in phosphate buffered saline (PBS) for 20 minutes at room temperature and processed for immunofluorescence analysis as described (Wobus et al., 2002). The following primary antibodies and dilutions were used: rabbit IgG anti-Pdx-1; 1:100; mouse IgG anti-Myc (Santa-Cruz Biotechnology, Santa Cruz, CA, http://scbt.com) 1:100; rabbit IgG anti-HA (Upstate, http://www.upstate.com) 1:100; mouse IgG anti-Nkx2.2 (Developmental Studies Hybridoma Bank, lowa City, IA, http://www.uiowa.edu/ dshbwww/) 1:50; rabbit lgG anti-Nkx6.1 (Dr Ole Madsen, Gentofte, Denmark) 1:1000; mouse IgG anti-nestin (Developmental Studies Hybridoma Bank) 1:3; rabbit IgG anti-Isl-1 (Abcam, http:/ /www.abcam.com) 1:50 guinea pig IgG anti-C-peptide (Linco Research, St. Charles, MO, http://www.lincoresearch.com) 1:100; and mouse IgG anti-insulin (Sigma) 1:100. The following secondary antibodies were used according to the manufacturer's recommendations: FITC-conjugated anti-mouse IgG and FITC-conjugated anti-rabbit IgG (both from Molecular Probes Inc., Eugene, OR, http://www.probes.in vitrogen.com); FITCconjugated anti-guinea pig IgG and Cy3-conjugated anti-mouse IgG (all from Jackson ImmunoResearch Laboratories, West Grove, PA, http:// www.jackson immuno.com). Cells were observed with a Leica DMRE (Leica, Heerbrugg, Switzerland, http://www.leica.com) and a LSM 510 META confocal laser scanning microscope (Carl Zeiss Microlmaging, Inc., Thornwood, NY, http://www.zeiss.com).

\section{Flow cytometry}

Cells were dissociated with $0.25 \%$ trypsin-EDTA, fixed with $2 \%$ PFA in PBS at $4^{\circ} \mathrm{C}$ for 1 hour, and permeabilized in Tris Buffer Saline (TBS) + $0.1 \%$ Triton X-100. Non-specific binding was blocked with $10 \%$ normal goat serum for $20 \mathrm{~min}$ at room temperature. Cells were incubated overnight at $4^{\circ} \mathrm{C}$ with mouse IgG anti-Oct4 (Santa-Cruz Biotechnology) 1:1000 and with rabbit IgG anti-Nanog (e-bioscience, http:// www.ebioscience.com) 1:500. After several rinses in TBS, cells were exposed to affinity-purified goat anti-mouse or anti-rabbit IgG conjugated to FITC (Jackson ImmunoResearch Laboratories) for 1 hour at room temperature. Cells were analysed using FACS Canto II (BecktonDickinson). Fluorescence was measured at $488 \mathrm{~nm}$. Data were recorded and analysed using DiVa software.

\section{Immunoblotting}

ES cells were washed and scraped in ice-cold PBS, centrifuged and frozen at $-80^{\circ} \mathrm{C}$. Cell pellets were lysed in $20 \mathrm{mM}$ Hepes $\mathrm{pH} 7.4,150 \mathrm{mM}$ $\mathrm{NaCl}, 50 \mathrm{mM} \mathrm{NaF}, 1 \%$ Triton X-100, 0.5\% NP40, 1 mM dithiothreitol, $1 \mathrm{mM}$ sodium orthovanadate, $1 \mathrm{mM}$ phenylmethylsulfonyl fluoride and cocktail of protease inhibitor (Roche Diagnostic) for $1 \mathrm{hr}$ at $4^{\circ} \mathrm{C}$. Protein lysates were cleared by centrifugation (14,000 RPM for $20 \mathrm{~min}$ ). For immunoblotting, $50 \mu \mathrm{g}$ of total proteins were resolved by SDS-polyacrylamide gel electrophoresis and electroblotted onto nitrocellulose. After overnight treatment with blocking buffer $(50 \mathrm{mM}$ Tris-Hcl pH 7.6, $150 \mathrm{mM}$ $\mathrm{NaCl}, 0.1 \%$ tween, $5 \%$ dry milk), the membranes were probed with primary antibodies at the following dilutions: anti-Pdx1 (1:500); anti-HA (1:500); anti-Myc (1:600); anti-Nkx2.2 (1:150) and anti-Nkx6.1 (1:10,000). Blots were incubated with horseradish peroxidase-coupled anti-mouse or anti-rabbit and developed using enzymatic chemiluminescence reagents (ECL, Amersham, Buckinghamshire, U. K., http://www.amersham.com).

\section{Proliferation assay by BrdU incorporation}

To assess their proliferation capacity cells were incubated with $10 \mu \mathrm{M}$ 5-Bromo-2'-deoxyuridine (BrdU, Roche, Mannheim, Germany) for 24h. Cover slips were washed in PBS, incubated in $2 \mathrm{~N} \mathrm{HCl}$ at room temperature for $30 \mathrm{~min}$, and fixed in methanol:acetone $(7: 1, \mathrm{v} / \mathrm{v})$ at $-20^{\circ} \mathrm{C}$ for 10 min. After washing three times in PBS, $1 \%$ bovine serum albumin (BSA) in PBS was applied as a blocking agent for $30 \mathrm{~min}$, followed by incubation with primary rat anti-BrdU (clone BU1/75 [ICR1], Abcam Ltd., Cambridge, UK) and primary mouse anti-nestin antibodies (clone Rat 401, Developmental Studies Hybridoma Bank, lowa City, IA, diluted 1:3 in PBS) for 90 min, then secondary rabbit anti-rat (Cye-labeled, 1:800 in 1\% BSA in PBS Jackson ImmunoResearch Laboratories, West Grove, PA) and Alexa 488-labeled goat anti-mouse secondary antibodies (diluted 1:100 with $1 \%$ BSA in PBS, Molecular Probes, Eugene, OR) for $60 \mathrm{~min}$. Nuclei were stained by Hoechst 33342, and the cover slips were mounted in Dako Cytomation fluorescent mounting medium (Dako, Hamburg) on SuperFrost glass slides (Menzel, Braunschweig, Germany). BrdU-positive and nestinpositive cells in the EB outgrowths ( $n=10$ fields) were estimated as percentage of Hoechst 33342-labeled cells using the fluorescence microscope ECLIPSE E600 (Nikon) and the confocal laser scanning microscope LSM510 META (Zeiss, Munich, Germany).

\section{Acknowledgements}

We are grateful to Dr. C. Wright for the gift of $P d x-1$ mouse cDNA, G. Gradwohl for HA-tagged mouse Ngn-3, and M. German for hamster $N k x 2.2$ and Nkx6.1. This work was supported by research grants from the Association Française contre la Myopathie (INSERM/AFM) (P.S.), INSERM AVENIR programme (P.S.), the European Union $6^{\text {th }}$ Framework Programme (FunGenES, contract N'LSHG-CT-2003-503494) (P.S. and A.M.W.), Région Rhône-Alpes (programme Emergence) (P.S.) and Fondation Bettencourt-Schueller (P.S.). M.M. was a recipient of a fellowship from the Association pour la Recherche contre le Cancer (ARC). 


\section{References}

AHLGREN, U., PFAFF, S.L., JESSELL, T.M., EDLUND, T., EDLUND, H. (1997). Independent requirement for ISL1 in formation of pancreatic mesenchyme and islet cells. Nature 385: 257-260.

AHLGREN, U., JONSSON, J., JONSSON, L., SIMU, K., EDLUND, H. (1998). betacell-specific inactivation of the mouse Ipf1/Pdx1 gene results in loss of the betacell phenotype and maturity onset diabetes. Genes Dev 12: 1763-1768.

APELQVIST, A., LI, H., SOMMER, L., BEATUS, P., ANDERSON, D.J., HONJO, T., HRABE, D.E., ANGELIS, M., LENDAHL, U., EDLUND, H. (1999). Notch signalling controls pancreatic cell differentiation. Nature 400: 877-881.

ASSADY, S., MAOR, G., AMIT, M., ITSKOVITZ-ELDOR, J., SKORECKI, K.L., TZUKERMAN, M. (2001). Insulin production by human embryonic stem cells. Diabetes 50: 1691-1697.

BLYSZCZUK, P., CZYZ, J., KANIA, G., WAGNER, M., ROLL, U., ST-ONGE, L., WOBUS, A.M. (2003). Expression of Pax4 in embryonic stem cells promotes differentiation of nestin-positive progenitor and insulin-producing cells. Proc Natl Acad Sci USA 100: 998-1003.

BLYSZCZUK, P., ASBRAND, C., ROZZO, A., KANIA, G., ST-ONGE, L., RUPNIK, M., WOBUS, A.M. (2004). Embryonic stem cells differentiate into insulinproducing cells without selection of nestin-expressing cells. Int J Dev Biol 48: 1095-1104

BONNAL, C., HERRERA, P.L. (2008) Genes controlling pancreas ontogeny. Int. J. Dev. Biol. 52: 823-835

BONNER-WEIR, S., WEIR, G.C. (2005). New sources of pancreatic beta-cells. Nat Biotechnol 23: 857-861.

BOYD, A.S., WU, D.C., HIGASHI, Y., WOOD, K.J. (2008). A Comparison of Protocols used to Generate Insulin-producing Cell Clusters from Mouse Embryonic Stem Cells. Stem Cells 26: 1128-1137.

BROLEN, G.K., HEINS, N., EDSBAGGE, J., SEMB, H. (2005). Signals From the Embryonic Mouse Pancreas Induce Differentiation of Human Embryonic Stem Cells Into Insulin-Producing \{beta\}-Cell-Like Cells. Diabetes 54: 2867-2874.

CISSELL, M.A., ZHAO, L., SUSSEL, L., HENDERSON, E., STEIN, R. (2003). Transcription factor occupancy of the insulin gene in vivo. Evidence for direct regulation by Nkx2.2. J Biol Chem 278: 751-6.

D'AMOUR, K.A., BANG, A.G., ELIAZER, S., KELLY, O.G., AGULNICK, A.D., SMART, N.G., MOORMAN, M.A., KROON, E., CARPENTER, M.K., BAETGE, E.E. (2006) Production of pancreatic hormone-expressing endocrine cells from human embryonic stem cells. Nat Biotechnol 24: 1392-1401.

DELTOUR, L., LEDUQUE, P., BLUME, N., MADSEN, O., DUBOIS, P., JAMI, J., BUCCHINI, D. (1993). Differential expression of the two nonallelic proinsulin genes in the developing mouse embryo. Proc Natl Acad Sci USA 90: 527-531.

FLUCKIGER, A.-C., MARCY, G., MARCHAND, M., NĖGRE, D., COSSET, F.-L., MITALIPOV, S., WOLF, D., SAVATIER, P., \& DEHAY, C. (2006). Cell-cycle features of primate embryonic stem (ES) cells. Stem Cells 24: 547-556.

GASA, R., MREJEN, C., LEACHMAN, N., OTTEN, M., BARNES, M., WANG, J., CHAKRABARTI, S., MIRMIRA, R., GERMAN, M. (2004). Proendocrine genes coordinate the pancreatic islet differentiation program in vitro. Proc Natl Acad Sci USA 101: 13245-13250.

GRADWOHL, G., DIERICH, A., LEMEUR, M., GUILLEMOT, F. (2000). neurogenin3 is required for the development of the four endocrine cell lineages of the pancreas. Proc Natl Acad Sci USA 97: 1607-1611.

GRAPIN-BOTTON, A., MAJITHIA, A.R., MELTON, D.A. (2001). Key events of pancreas formation are triggered in gut endoderm by ectopic expression of pancreatic regulatory genes. Genes Dev 15: 444-454.

GU, G., DUBAUSKAITE, J., MELTON, D.A. (2002). Direct evidence for the pancreatic lineage: NGN3+ cells are islet progenitors and are distinct from duct progenitors. Development 129: 2447-57.

HEREMANS, Y., VAN DE CASTEELE, M., IN'T VELD, P., GRADWOHL, G., SERUP, P., MADSEN, O., PIPELEERS, D., HEIMBERG, H. (2002). Recapitulation of embryonic neuroendocrine differentiation in adult human pancreatic duct cells expressing neurogenin 3. J Cell Biol 159: 303-312.

HOLLAND, A.M., HALE, M.A., KAGAMI, H., HAMMER, R.E., MACDONALD, R.J. (2002). Experimental control of pancreatic development and maintenance. Proc Natl Acad Sci USA 99: 12236-12241.
JENSEN, J. (2004). Gene regulatory factors in pancreatic development. Dev Dyn 229: $176-200$.

JIANG, J., AU, M., LU, K., ESHPETER, A., KORBUTT, G., FISK, G., MAJUMDAR, A.S. (2007). Generation of Insulin-producing Islet-like Clusters from Human Embryonic Stem Cells. Stem Cells 25: 1940-1953.

JONSSON, J., CARLSSON, L., EDLUND, T., EDLUND, H. (1994). Insulin-promoter-factor 1 is required for pancreas development in mice. Nature 371: 606609.

KAHAN, B.W., JACOBSON, L.M., HULLETT, D.A., OCHOADA, J.M., OBERLEY, T.D., LANG, K.M., ODORICO, J.S. (2003). Pancreatic precursors and differentiated islet cell types from murine embryonic stem cells: an in vitro model to study islet differentiation. Diabetes 52: 2016-2024.

KANETO, H., NAKATANI, Y., MIYATSUKA, T., MATSUOKA, T.A., MATSUHISA, M., HORI, M., YAMASAKI, Y. (2005). PDX-1/VP16 fusion protein, together with NeuroD or Ngn3, markedly induces insulin gene transcription and ameliorates glucose tolerance. Diabetes 54: 1009-1022.

KOJIMA, H., FUJIMIYA, M., MATSUMURA, K., YOUNAN, P., IMAEDA, H., MAEDA, M., CHAN, L. (2003). NeuroD-betacellulin gene therapy induces islet neogenesis in the liver and reverses diabetes in mice. Nat Med 9: 596-603.

KROON, E., MARTINSON, L.A., KADOYA, K., BANG, A.G., KELLY, O.G., ELIAZER, S., YOUNG, H., RICHARDSON, M., SMART, N.G., CUNNINGHAM, J., AGULNICK, A.D., D'AMOUR, K.A., CARPENTER, M.K., BAETGE, E.E. (2008). Pancreatic endoderm derived from human embryonic stem cells generates glucose-responsive insulin-secreting cells in vivo. Nat Biotechnol 26: 443-452.

KUMAR, M., JORDAN, N., MELTON, D., GRAPIN-BOTTON, A. (2003). Signals from lateral plate mesoderm instruct endoderm toward a pancreatic fate. Dev Biol 259: 109-122.

LAVON, N., YANUKA, O., BENVENISTY, N. (2006). The effect of over expression of Pdx1 and Foxa2 on the differentiation of human embryonic stem cells into pancreatic cells. Stem Cells 24: 1923-1930.

MANGEOT, P.E., NEGRE, D., DUBOIS, B., WINTER, A.J., LEISSNER, P., MEHTALI, M., KAISERLIAN, D., COSSET, F.L., DARLIX, J.L. (2000) Development of minimal lentivirus vectors derived from simian immunodeficiency virus (SIVmac251) and their use for gene transfer into human dendritic cells. J Virol 74: 8307-8315.

MIYAZAKI, S., YAMATO, E., MIYAZAKI, J. (2004). Regulated expression of pdx1 promotes in vitro differentiation of insulin-producing cells from embryonic stem cells. Diabetes 53: 1030-1037.

MURTAUGH, L.C. (2007). Pancreas and beta-cell development: from the actual to the possible. Development 134: 427-438.

NAYA, F.J., STELLRECHT, C.M., TSAI, M.J. (1995). Tissue-specific regulation of the insulin gene by a novel basic helix-loop-helix transcription factor. Genes Dev 9: 1009-1019.

NAYA, F.J., HUANG, H.P., QIU, Y., MUTOH, H., DEMAYO, F.J., LEITER, A.B., TSAI, M.J. (1997). Diabetes, defective pancreatic morphogenesis, and abnormal enteroendocrine differentiation in BETA2/neuroD-deficient mice. Genes Dev 11: 2323-2334.

NEGRE, D., MANGEOT, P.E., DUISIT, G., BLANCHARD, S., VIDALAIN, P.O., LEISSNER, P., WINTER, A.J., RABOURDIN-COMBE, C., MEHTALI, M., MOULLIER, P., DARLIX, J.L., COSSET, F.L. (2000). Characterization of novel safe lentiviral vectors derived from simian immunodeficiency virus (SIVmac251) that efficiently transduce mature human dendritic cells. Gene Ther 7: 16131623.

NIR, T., DOR, Y. (2005). How to make pancreatic beta cells - prospects for cell therapy in diabetes. Curr Opin Biotechnol 16: 524-529.

OFFIELD, M.F., JETTON, T.L., LABOSKY, P.A., RAY, M., STEIN, R.W., MAGNUSON, M.A., HOGAN, B.L., WRIGHT, C.V. (1996). PDX-1 is required for pancreatic outgrowth and differentiation of the rostral duodenum. Development 122: 983-995.

RUDNICK, A., LING, T.Y., ODAGIRI, H., RUTTER, W.J., GERMAN, M.S. (1994). Pancreatic beta cells express a diverse set of homeobox genes. Proc Natl Acad Sci USA 91: 12203-12207.

SAITOH, K., YAMATO, E., MIYAZAKI, S., MIYAZAKI, J. (2007). Both Pdx-1 and NeuroD1 genes are requisite for the maintenance of insulin gene expression in ES-derived differentiated cells. Diabetes Res Clin Pract77 Suppl 1: S138-S142. SANDER, M., SUSSEL, L., CONNERS, J., SCHEEL, D., KALAMARAS, J., DELA 
CRUZ, F., SCHWITZGEBEL, V., HAYES-JORDAN, A., GERMAN, M. (2000). Homeobox gene Nkx6.1 lies downstream of Nkx2.2 in the major pathway of beta-cell formation in the pancreas. Development 127: 5533-5540.

SAVATIER, P., LAPILLONNE, H., VAN GRUNSVEN, L.A., RUDKIN, B.B., SAMARUT, J. (1996). Withdrawal of differentiation inhibitory activity/leukemia inhibitory factor up-regulates $D$-type cyclins and cyclin-dependent kinase inhibitors in mouse embryonic stem cells. Oncogene 12: 309-322.

SCHROEDER, I.S., KANIA, G., BLYSZCZUK, P., WOBUS, A.M. (2006). Insulinproducing cells. Methods Enzymol 418: 315-333.

SCHWITZGEBEL, V.M., SCHEEL, D.W., CONNERS, J.R., KALAMARAS, J., LEE, J.E., ANDERSON, D.J., SUSSEL, L., JOHNSON, J.D., GERMAN, M.S. (2000). Expression of neurogenin3 reveals an islet cell precursor population in the pancreas. Development 127: 3533-4352.

SHIROI, A., UEDA, S., OUJI, Y., SAITO, K., MORIYA, K., SUGIE, Y., FUKUI, H., ISHIZAKA, S., YOSHIKAWA, M. (2005). Differentiation of embryonic stem cells into insulin-producing cells promoted by Nkx2.2 gene transfer. World $J$ Gastroenterol 11: 4161-4166.

SMITH, A.G. (2001). Embryo-derived stem cells: of mice and men. Annu Rev Cell Dev Biol 17: 435-462.

SOSA-PINEDA, B., CHOWDHURY, K., TORRES, M., OLIVER, G., GRUSS, P.
(1997). The Pax4 gene is essential for differentiation of insulin-producing beta cells in the mammalian pancreas. Nature 386: 399-402.

SUSSEL, L., KALAMARAS, J., HARTIGAN-O'CONNOR, D.J., MENESES, J.J., PEDERSEN, R.A., RUBENSTEIN, J.L., GERMAN, M.S. (1998). Mice lacking the homeodomain transcription factor Nkx2.2 have diabetes due to arrested differentiation of pancreatic beta cells. Development 125: 2213-2221.

TAKAYAMA, I., MIYAZAKI, S., TASHIRO, F., FUJIKURA, J., MIYAZAKI, J., YAMATO, E. (2008). Pdx-1-independent differentiation of mouse embryonic stem cells into insulin-expressing cells. Diabetes Res Clin Pract 79: e8-10.

TREFF, N.R., VINCENT, R.K., BUDDE, M.L., BROWNING, V.L., MAGLIOCCA, J.F., KAPUR, V., ODORICO, J.S. (2006). Differentiation of Embryonic Stem Cells Conditionally Expressing Neurogenin 3. Stem Cells 24: 2529-2537.

VACA, P., MARTIN, F., VEGARA-MESEGUER, J.M., ROVIRA, J.M., BERNA, G., SORIA, B. (2006). Induction of differentiation of embryonic stem cells into insulin-secreting cells by fetal soluble factors. Stem Cells 24: 258-265.

WOBUS, A.M., BOHELER, K.R. (2005). Embryonic stem cells: prospects for developmental biology and cell therapy. Physiol Rev 85: 635-678.

WOBUS, A.M., GUAN, K., YANG, H.T., BOHELER, K.R. (2002). Embryonic stem cells as a model to study cardiac, skeletal muscle, and vascular smooth muscle cell differentiation. Methods Mol Biol 185: 127-156.

\section{Further Related Reading, published previously in the Int. J. Dev. Biol.}

See our recent Special Issue Fertilization, in honor of David L. Garbers and edited by Paul M. Wassarman and Victor D. Vacquier at: http://www.ijdb.ehu.es/web/contents.php?vol=52\&issue=5-6

Genes controlling pancreas ontogeny

Claire Bonal and Pedro L. Herrera

Int. J. Dev. Biol. (2008) 52: 823-835

Expression of regulatory genes for pancreas development during murine embryonic stem cell differentiation

Josué K. Mfopou, Erik Willems, Luc Leyns and Luc Bouwens

Int. J. Dev. Biol. (2005) 49: 915-922

Embryonic stem cells differentiate into insulin-producing cells without selection of nestin-expressing cells

Przemyslaw Blyszczuk, Christian Asbrand, Aldo Rozzo, Gabriela Kania, Luc St-Onge,

Marjan Rupnik and Anna M. Wobus

Int. J. Dev. Biol. (2004) 48: 1095-1104

The generation of insulin-producing cells from embryonic stem cells - a discussion of controversial findings

Gabriela Kania, Przemyslaw Blyszczuk and Anna M. Wobus

Int. J. Dev. Biol. (2004) 48: 1061-1064

Role of cell division in branching morphogenesis and differentiation of the embryonic pancreas

L D Horb and J M Slack

2006 ISI **Impact Factor $=3.577^{* *}$

Int. J. Dev. Biol. (2000) 44: 791-796 